\title{
The Burnum Project: a combination of archaeological research and communication in Cultural Heritage
}

The archaeological site of Burnum is the subject of scientific research conducted since 2005 by the members of the Department of History, Culture and Civilization of Bologna University in collaboration with the Department of Archaeology of the University of Zadar. The project makes use of the fundamental support of the Krka National Park, committed to protecting the environmental heritage of the river valley and from 2003 also to enhancing the rich historical and archaeological context of the area. In this regard, while the research activities at Burnum continue to return new data and information on the history of the site during the Roman period, the project is also focusing on issues concerning virtual reconstruction and multimedia technologies applied to cultural heritage, with the aim of capturing attention, simplifying understanding and removing usage patterns.

\section{Introduction}

Burnum is not only a legionary fort for which it is possible to reconstruct in many of its aspects the spatial organization and the architectural component of its buildings, but also one of the few Roman military sites where you can understand the transformation from castrum to civilian settlement. The archaeological evidence, although extraordinarily important from a scientific point of view, is however of little visual impact since, with the exception of the monumental arches referable to the forum basilica and the remains of the amphitheatre recently brought to light, the ancient structures still lie underground and even when archeologically investigated.

These conservation characteristics of the site, together with the fact that the area is part of a National Kark known for its natural and environmental beauty, has immediately prompted the researchers involved in the Burnum project to direct research towards methods of non-invasive investigation that were able to acquire the most information on the site, without resorting to extensive excavations, and towards forms of communication of the results that can tell in a clear, understandable and compelling way the progressive development of research in Burnum without distorting the current landscape. 
In recent times, in fact, technological evolution has significantly increased the possibilities of archaeological research, while the availability of new multimedia tools is profoundly renewing the way of telling it. With the intention of experimenting and testing new research methodologies, but also modern forms and languages of communication, the entire project is constantly updated on new orientations and good practices involving preventive and digital archaeology.

\section{Present State of Research}

In recent years, several articles have been published concerning the archaeological site of Burnum. This publication activity has greatly improved our knowledge on different aspects related to the appearance of the legionary castrum later transformed into a town hall (Campedelli 2012) and on the intense building activity that has affected some specific archi-

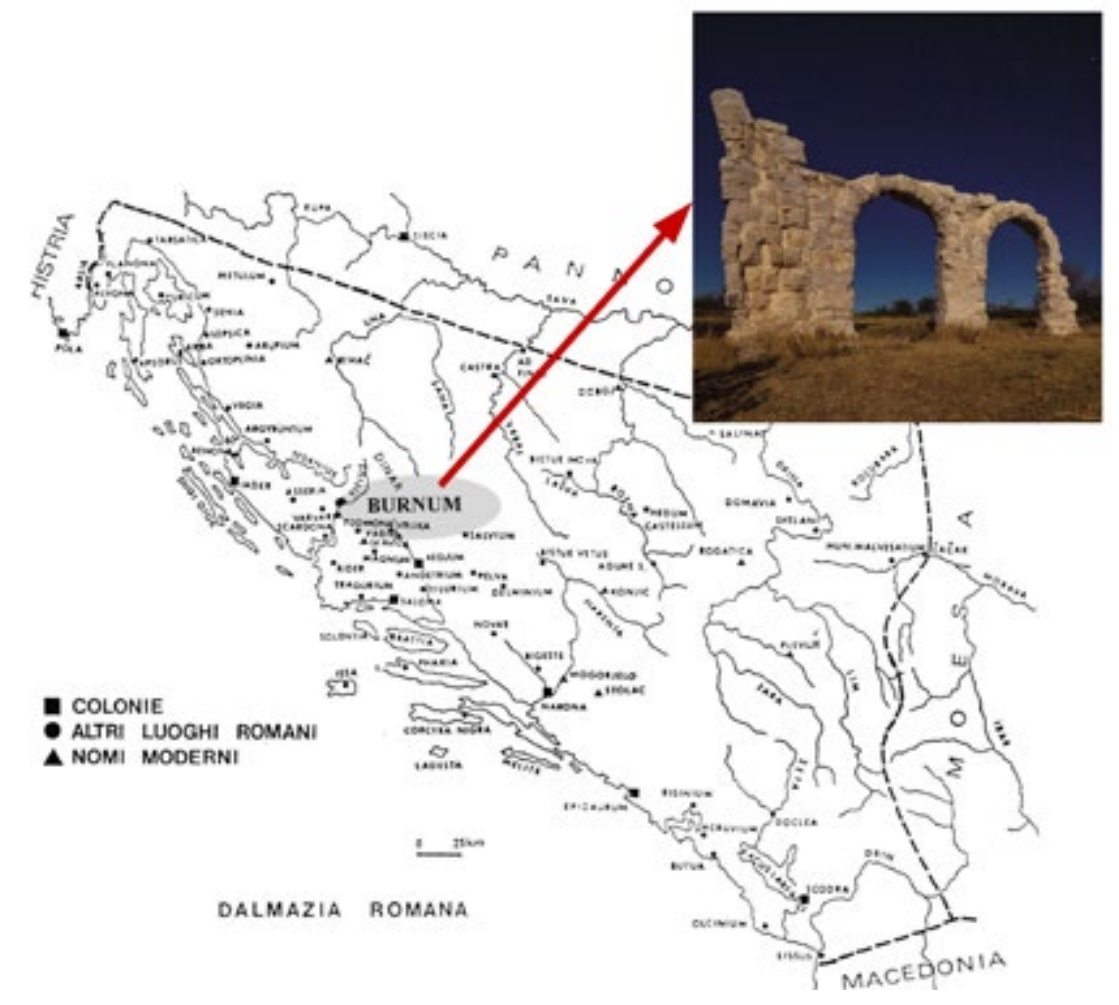

Fig. 1. The Roman province of Dalmatia and the location of the Burnum archaeological site tectural contexts (Miletić, 2010). The numerous finds and objects of the material culture allowed to contextualize from a chronological point of view the different phases of the life of the settlement (Campedelli, Gruska, Morsiani, 2018), as well as to clarify the organization of the supply of the castrum (Borzić, 2012) and the trade routes that connected the city to the rest of the Empire. (Borzić, 2014)

These results mainly derive from the extensive excavations carried out by Croatian colleagues in the amphitheatre (Glavičić, Miletić, 2009) and the nearby campus (Glavaš 2012), and with small targeted essays by the staff of the University of Bologna inside the castrum/municipium, however, it is worth remembering that one of the main sources of understanding of the historical content, of general development of the ancient agglomeration and of its inclusion within a wider territorial context is derived from non-invasive methodologies that exploit in particular geophysical surveys, aerial photography and remote sensing. 


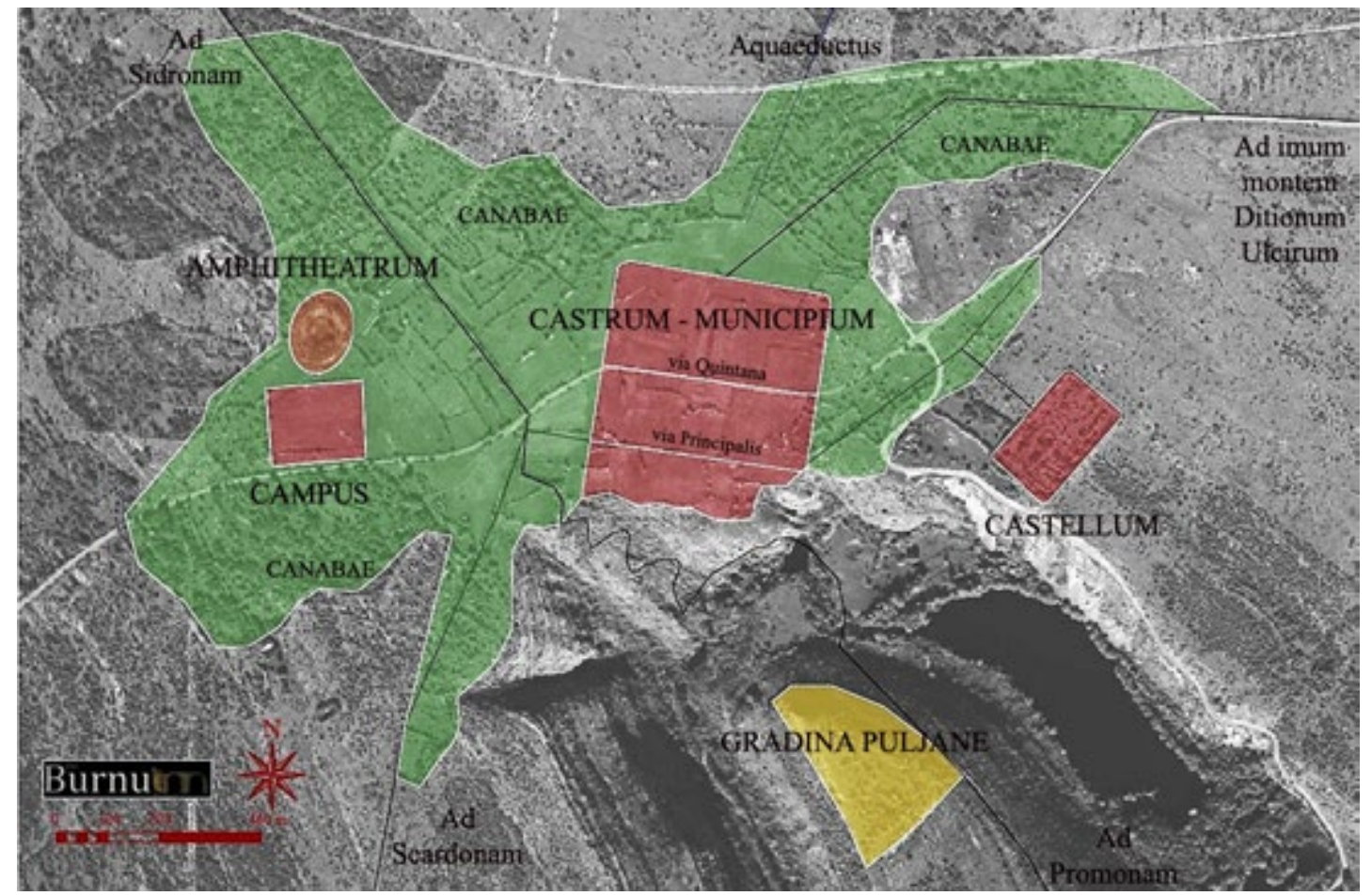

Fig. 2. Archaeological topography of the site (Campedelli, Giorgi 2018, 17)

It is no coincidence that since 2005 this modus operandi has been the choice made by the researchers of the University of Bologna with the Burnum project and implemented with the valuable contribution of Croatian colleagues and many other scholars of different disciplines. (Campedelli 2007; Boschi, Giorgi, 2012)

In this way, the combination of different methods of geophysical exploration has returned new and interesting information useful for a proper understanding of the planimetric contexts of the site, their consistency, as well as for their recomposition within the ancient urban system, (Boschi 2011; Giorgi 2016) while the observations made from above through the processing of multispectral images from satellite (Campedelli, Dubbini, Monica, 2017) or the analysis of historical photographs (Dubbini 2016) have shed new light on the extent of the site, on the extra-uban road network connecting with the other centers of the province and more generally on the territorial organization of the middle and upper valley of Krka in Roman times.

The renewed interest in this important Croatian site and the intense research activity then carried out served as a driving force for further insights and new discoveries made by researchers and scholars more or less involved in the project, among which it is certainly worth mentioning the identification of additional Roman forts to protect the crossing of the river canyon. (Cesarik 2017, Vitale 2017; Vrkić 2017) 


\section{Promotion of activities and results achieved}

The sharing and communication through the specialized and specialistic channel of the scientific magazines and conferences, even if fortunately prolific, has not been the only way to spread the many results of the progress made by the archaeological research in Burnum. "If the past belongs to everyone, the

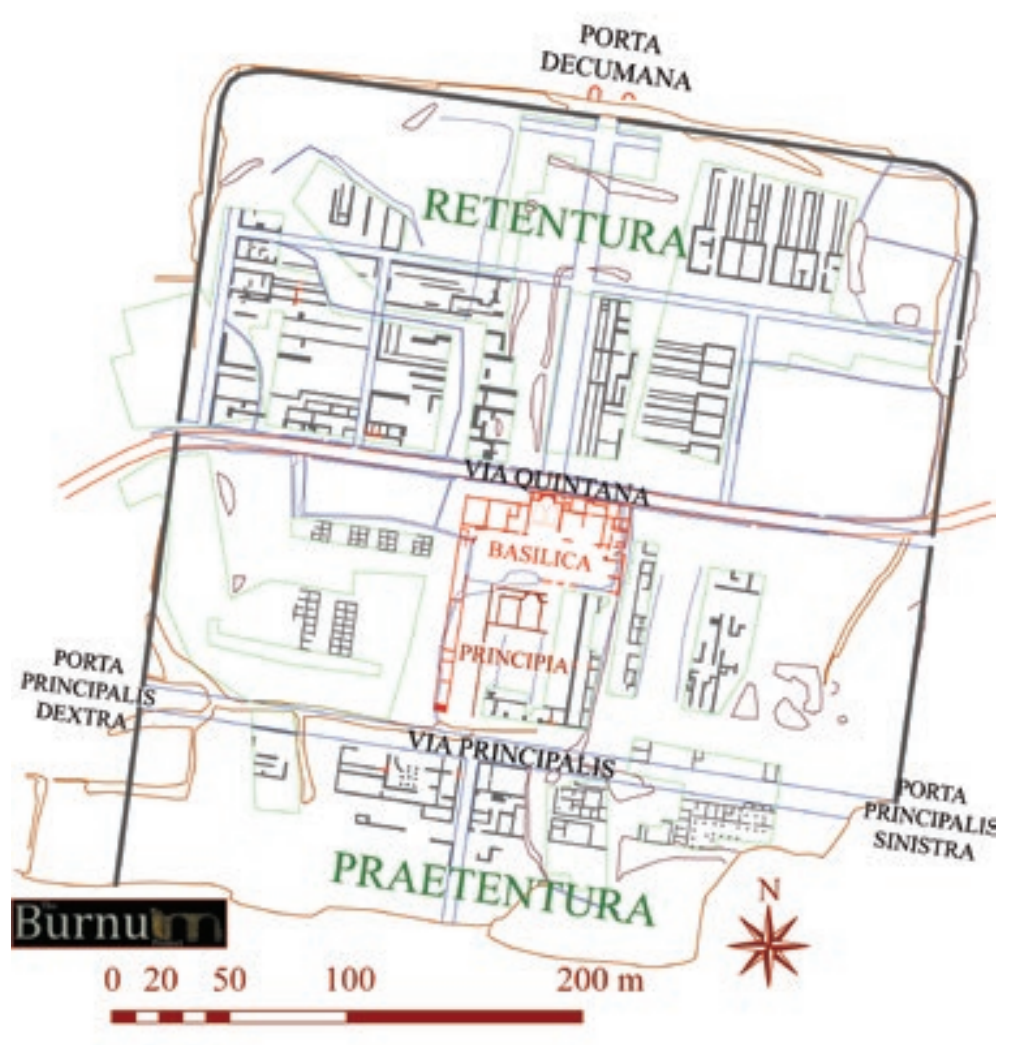

Fig. 3. Interpretation of geophysical anomalies (Campedelli, Giorgi 2018, 57) problem shifts to the forms in which to put everyone in a position to possess it, that is, to know it". (Manacorda 2007). The dispute, in fact, is that the archaeological remains, more or less preserved, have the ability to tell stories, but they do so in a fragmentary and disorganized way, in many cases whispering or speaking a language that is not always easy to understand.

It was therefore essential, from the very beginning, that the development of research in the field of conservation, documentation and study of the cultural heritage of Burnum was made known and understood to a wider audience of non-experts, both to establish a more vital and correct relationship between archaeology and society, both to safeguard the cultural heritage and landscape, and, finally, to create new employment opportunities.

This awareness, supported and strengthened by the fact that the site is located within one of the most visited nature parks in Croatia, the Krka National Park, has led the partners involved in the project to choose to publish in several languages, and with an almost annual frequency, a series of small volumes written in a simple way and accompanied by many images, graphics and thematic maps. Among the first examples of this initiative it is worth mentioning the booklet Rimska vojska $u$ Burnumu of 2007, (Cambi et al. 2007) while the last commitment in this direction is the volume sponsored by the Italian Institute of Culture in Zagreb and published in 2018: Ricerche della Missione archeologica dell'Università di Bologna in Croazia (2005-2015). (Campedelli, Giorgi 2018) 


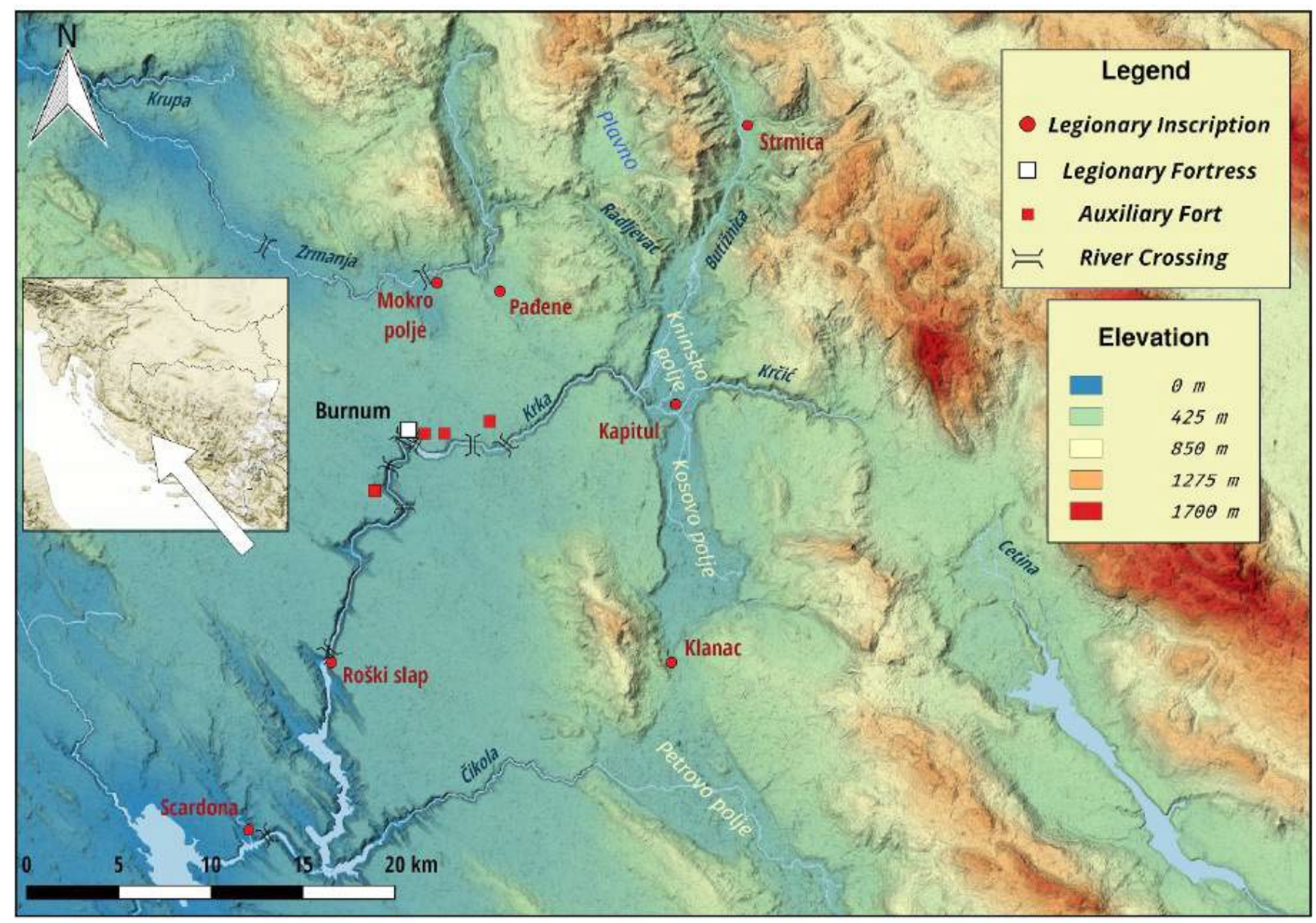

\section{D Reconstructions for archaeological communication}

In the communication of knowledge about the built, architectural and urban space of an archaeological site, the effectiveness of the types of explorations based on virtual perceptual criteria, which have as their foundation the interaction of the user with the three-dimensional space of the cultural site, plays an increasingly decisive role. (RIPANTI 2013) The innovative and dynamic reconstructions in 3D and the simulations in virtual reality offer, in fact, great possibilities to present a building in the dimension of its transformation processes. Over the years, therefore, there have been occasions when the Burnum project has also promoted experiences aimed at proposing reconstructive hypotheses, as for example in the case of the forum basilica of which the monumental arches were part, with products initially only static, but of great visual impact.

The possibility of updating the data through ever faster and more precise methods of acquisition and of perfecting the way in which they can be used with ever more advanced modelling software are directing the subjects involved in the Burnum
Fig. 4. Military occupation of the middle and upper Krka valley in Roman times ( $\mathrm{Ce}$ sarik 2017, 364) 


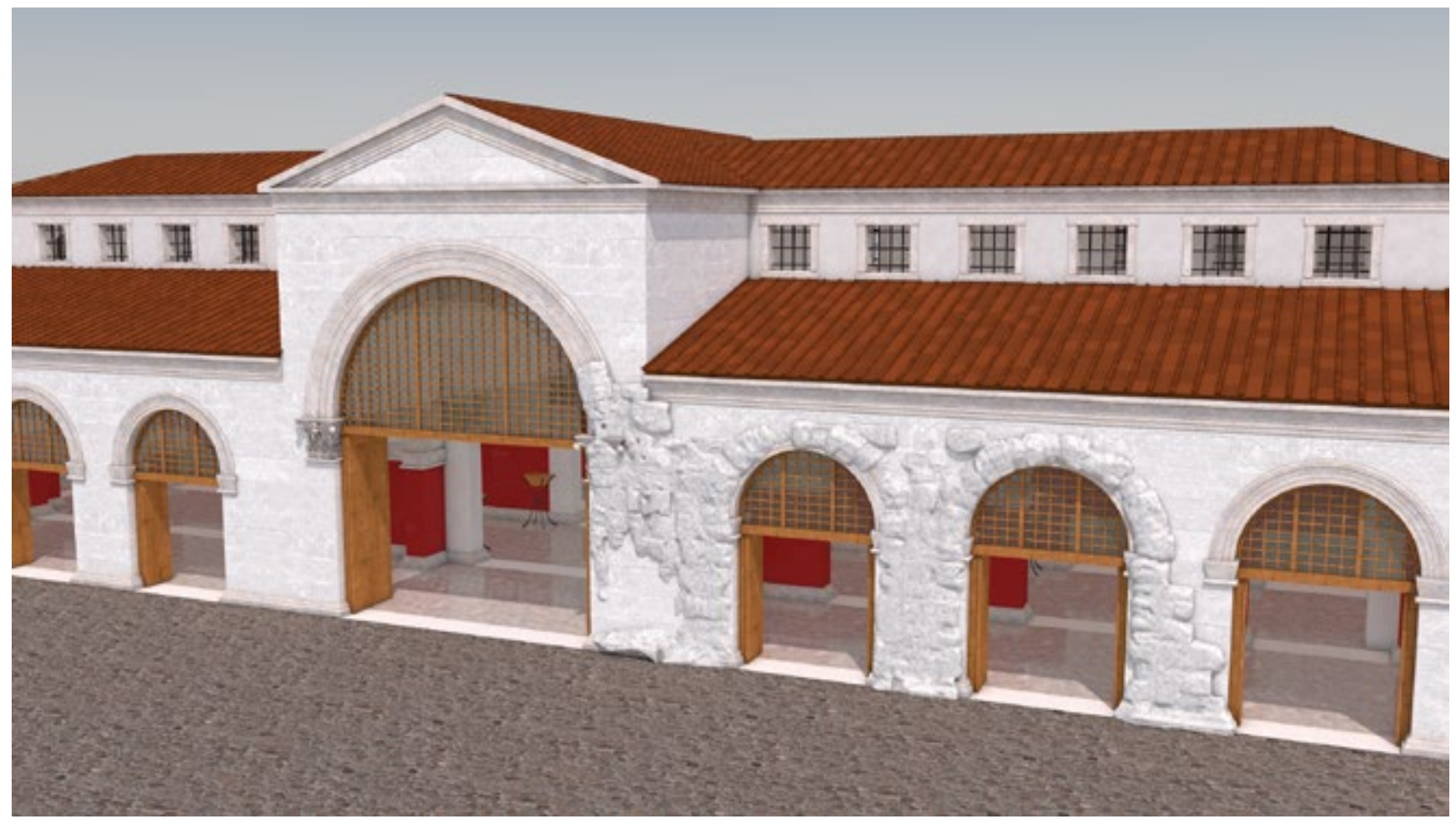

Fig. 5. Hypothetical reconstruction of the Burnum civil basilica (Campedelli, Giorgi 2018, 71) project to create virtuous paths to restore vitality to the ruins and monuments of the past.

In the wake of the innovative process that now involves the world of Cultural Heritage and thanks to the constant commitment of the Krka National Park towards the enhancement and enjoyment of tourism, the challenge taken up in Burnum is to enhance the presentation of the results obtained so far through strategies of audience development and public engagement that exploit digital tools and multimedia products.

Part of this new program of integrated data management aimed at ensuring better conditions of use of the archaeological heritage of Burnum to all types of audiences, the project for the development of representative models and 3D digital reconstructions of the Roman amphitheatre with which a video-documentary will be made that traces the entire history of the monument, paying attention to the evolution of its construction characteristics over time. 


\section{Bibliography}

Borzić, Igor. 2012. "Hispanski garum na burnumskom stolu", in Archaeologica Adriatica 5, 65-88.

2014, "Radionički pečati na italskoj tera sigilati iz Burnuma", in: Archaeologica Adriatica 7/1, 133-150.

Boschi, Federica. 2011. "Geophysical survey of the Burnum archaeological site, Croatia”, in: Archaeological Prospection 18, 117 - 128.

Boschi, Federica, Enrico Giorgi. 2012. “The Burnum Project: An Integrated Approach to the Study of a Roman Castrum in Croatia", in Urban Landscape Survey in Italy and Mediterranean edited by F. Vermeulen, G.J. Burgers and C. Corsi. Oxford: Oxbow Books170-179.

Cambi, Nenad, Miroslav Glavičić, Dražen Maršić, Željko Miletić and Joško Zaninović 2007. Rimska vojska u Burnumu, katalozi i monografije / NP Krka 2. Drniš : Gradski muzej.

Campedelli Alessandro. 2007. "Il Progetto Burnum (Croazia)", in: Ocnus 15, 57-78.

. 2012. "The Castrum of Burnum: between old Excavations and new Researches", in: Archaeologia Adriatica 5, 33-64.

Campedelli Alessandro, Dubbini Marcoa and Monica Martina. 2017, "Geo-archaeological study of the territory of Burnum's Roman site (Croatia) through LANDSAT multi-temporal satellite images and high resolution GeoEye", in: Archeologia e Calcolatori 28.2, 277-290.

Campedelli Alessandro, Gruska Bojnaand Morsiani Sara. 2018."L'abbandono di Burnum: analisi delle fonti storiche ed archeologiche e dati sulla cultura materiale", in Economia e territorio. L'Adriatico centrale tra tarda Antichità e alto Medioevo edited by Enrico Cirelli, Enrico Giorgi and Giuseppe Lepore BAR international series, 2926. Oxford: BAR Publishing, 511- 524.

Campedelli Alessandro, Enrico Giorgi. 2018. Burnum Project : ricerche della missione archeologica dell'Università di Bologna in Croazia (2005-2015) = Burnum Project: archeološka misija bolonjskog Sveučilišta u Hrvatskoj (2005.-2015.g.). Bologna: Ante quem.

Cesarik Nikola 2017. "River Crossings and Roman Auxiliary Forts: A New Evidence from the River Krka", in: Collegium Antropologicum 41/4, 363-370.

Dubbini Marco. 2016. "Visualizzare un sito archeologico: rappresentazioni e analisi applicate al sito di Burnum", in Visualizzare il paesaggio. Nuove forme di narrazione e rappresentazione dello spazio geografico, edited by Martina Giannini, Valentina Greco. Quaderni di Storicamente, 9. Bologna: Bradypus, 11-36.

Glavaš Vedrana. 2012, “Antefixa with Depictions of tragic Masks from Burnum and Asseria”, in: Archaeologica Adriatica 5, 89-103.

Glavičić Miroslav and Željko Miletić. 2009. "Excavations of the legionary amphitheatre at Burnum", in: Roman Amphitheatres and Spectacula: a 21st-Century Perspective, edited by Tony Wilmott. Oxford: Archaeopress, 75-84. 
Giorgi Enrico 2016. "City archaeology in the Adriatic area: The cases of Burnum in Dalmatia and Suasa and Ascoli in the Marche region", in: Looking to the future, caring for the past: preventive archaeology in theory and practice; proceedings of the 2013-2014 Erasmus IP Summer Schools in Preventive Archaeology : evaluating sites and landscapes: methods and techniques for evaluating the archaeological value edited by Federica Boschi, Bologna: Bononia University Press , 109-115.

Manacorda Daniele. 2007. Il sito archeologico: fra ricerca e valorizzazione. Roma: Carocci

Miletić, Željko. 2010. "Burnum - A Military Centre in the Province of Dalmatia", in Finds of the Roman Military Equipment in Croatia edited by Ivan Radman-Livaja and Mato Ilkić. Zagreb: Arheološki Muzej, 113-141.

Ripanti, Francesco. 2013. "Ricostruzioni, 3d e narratività: strategie diversificate per la comunicazione dell'archeologia", in: Archeologia e Calcolatori, Supplemento 4,174-180.

Vitale, Saša 2017, "Otkrića novih rimskih logora na desnoj obali Krke” in Vizija $i$ izazovi upravljanja zaštićenim područjima prirode u Republici Hrvatskoj: aktivna zaštita i održivo upravljanje u Nacionalnom parku, Krka, edited by D.Marguš. Drniš, 867-887.

Vrkić, Šime. 2017. "Toward archaeological topography of the village of Radučić near Knin”, in: Diadora 31, 197-222. 